\title{
Small airways dysfunction among non-smoking shipyard arc welders
}

\author{
Ulf Hjortsberg, Palle Ørbæk, Måns Arborelius Jr
}

\begin{abstract}
Increased volume of trapped gas (VTG), indicating small airways dysfunction, was found among 14 never smoking non-atopic welders who had worked for 10-31 (mean 22) years in their occupation.

Spirometry and nitrogen wash out data were compared with those from a reference group of 14 never smoking men not exposed to welding. A methacholine provocation test was carried out. The effect was measured by change in forced expiratory volume in one second $\left(F E V_{1}\right)$ and VTG. The maximum decrease in $F E V_{1}$ after inhalation of methacholine was $6 \%$ in welders and $2 \%$ among referents. Before provocation VTG and VTG total lung capacity (TLC) was higher among welders (127 ml $v 98 \mathrm{ml}$ and $1.76 \% v 1.38 \%)$. The increase in VTG and VTG/TLC was higher in welders after inhalation of methacholine at concentrations of $0.001 \%$ to $2 \%$ and remained increased after inhalation of salbutamol. The differences indicate small airways disease among shipyard welders.
\end{abstract}

Manual metal arc welding produces airborne particles of which $50 \%$ are in the diameter range 0.3 to $0.6 \mu \mathrm{m}$, thus they are respirable and likely to deposit in small airways or alveoli. Small airways are defined as airways having a diameter smaller than $2 \mathrm{~mm} .^{1}$ It is suggested that small airways disease might be a forerunner of chronic obstructive lung disease. ${ }^{23}$ Because the total luminal cross section is very large in peripheral lung, small airways disease will cause no major alteration in the total airways resistance $\left(R_{a w}\right)$ and is not detected by methods using tests for resistance in large

Department of Occupational Medicine U Hjortsberg, P Ørbæk

Department of Clinical Physiology, Malmö General Hospital, S-214 01 Malmö, Sweden

M Arborelius Jr airways such as forced expiratory volume in one second $\left(\mathrm{FEV}_{1}\right)$. Cigarette smoking may induce small airways disease in subjects with normal function in the large airways. ${ }^{4}$ Accumulation of welding particles in small airways increases production of mucus and leads to stagnation of secretion. ${ }^{5}$ Welders have been reported to have more cough, shortness of breath, and wheezing than referents. ${ }^{6-7}$

To study small airways we measured volume of trapped gas (VTG) in the lung by using the nitrogen wash out technique..$^{8-9}$ In a previous study we found an increase in VTG after methacholine provocation among symptom free workers in occupational low exposure to isocyanate. ${ }^{10}$ Our hypothesis was that welding fume and particles would cause small airways disease detectable by an increase in VTG.

\section{Material}

From the employment lists of a shipbuilding company 14 never smoking arc welders were selected by the health care nurse. Inclusion criteria for the study were: a never smoker, no previous symptoms of bronchitis, no pulmonary disease, and normal pulmonary $x$ ray film. None of the welders had previously sought medical attention for pulmonary complaints and did not report any previous allergic symptoms. They lived in an urban area with no heavily polluted atmosphere. An indirect exposure to asbestos could not, however, be ruled out as asbestos was used for many years in the shipyard. Mean age was 46 (range 3356) years, mean height was 173 (range 165-182) $\mathrm{cm}$, mean weight was 77 (range 64-98) kg, and mean blood IgE concentration was 21 (range 2-75) $\mathrm{ku} / \mathrm{l}$. The welders had been exposed to welding fumes for 10-31 (mean 22) years.

Reference values were obtained from 14 nonatopic healthy, mainly white collar, working men without exposure to airway irritating fumes or gases. They had no history of allergic predisposition. Blood IgE concentrations were not measured in reference subjects. Mean age was 35 
(range 24-56) years, mean height was 179 (range $158-190$ ) cm, and mean weight was 72 (range 58$82) \mathrm{kg}$.

\section{Methods}

Spirometry was performed with a Bernstein type spirometer. Wash out volume (WOV) is the exhaled volume during a multiple breath wash out procedure to $2 \%$ nitrogen in end expired air. Volume of trapped gas was determined by rebreathing of oxygen with maximum breaths at the end of the nitrogen wash out. The nitrogen concentration in exhaled air was continuously measured by a nitrogen meter (Ohio 700 nitrogen analyser, Ohio Medical Products, Houston, TX). The VTG was calculated by the equation: VTG $=\left(\right.$ TLC $\left.\left.\times \mathrm{FN}_{2} \mathrm{ER}-\mathrm{FRC} \times 0.02\right)\right) 0.8$ where $\mathrm{FN}_{2} \mathrm{ER}$ is the nitrogen concentration in the lung bag system at the end of the rebreathing period, FRC is the functional residual capacity, and TLC is the total lung capacity. The coefficient of variation for VTG is $\mathbf{9 \cdot 2 \%}$. ${ }^{9}$ Volume for FRC was calculated from the nitrogen wash out down to $2 \%$ in expired air. Spirometry was carried out and VTG was measured before and after inhalation provocation with methacholine at increasing concentrations by 10 times potential from $0.001 \%$ to $1 \%$, by $2 \%$ methacholine, and after salbutamol. The aerosol apparatus (Pari Inhaler Boy) was driven by compressed air at $200 \mathrm{Kpa}$ with the top vent closed and with an output of $26 \mathrm{ml} \mathrm{min}^{-1}$. Under these conditions about $40 \%$ of retained aerosol is deposited distal to the main bronchi, the rest mainly in the mouth, larynx, and stomach. ${ }^{11}$

Total serum IgE concentration was measured by the PRIST test (Pharmacia Diagnostics AB, Uppsala, Sweden). Predicted values for spirometry were obtained from 100 healthy men aged from 20 to 70 with 20 subjects in each age decade examined at our laboratory..$^{9}$ These have been presented previously. ${ }^{12}$

\section{Statistics}

Group comparisons were made with the MannWhitney $\mathrm{U}$ test. The $\mathrm{p}$ values given are two tailed.

\section{Results}

Table 1 presents the mean values and ranges for static and dynamic lung volumes and wash out volume for the welders $(n=14)$ and controls $(n=14)$. The welders had larger lung volumes, despite being shorter and older than controls. To compensate for the difference in total lung capacity (TLC) between welders and controls VTG/TLC was calculated. Table 2 gives the results from the methacholine provocation test. At all concentrations of methacholine the welders had a greater increase of VTG than the control group. They did not completely revert to the initial values after inhalation of the $\beta$-2-agonist salbutamol (Ventolin). For the welders the reduction in $\mathrm{FEV}_{1}$ was $6 \%$ and the increase in VTG was $179 \%$ after inhalation of $2 \%$ methacholine. Correlation between fall in FEV and increase in VTG was not significant at any level of provocation. No consistently positive correlations were found for the increase in VTG at different methacholine concentrations and exposure years for welding fume.

\section{Discussion}

Our main result was the increase of VTG in welders, which indicates dysfunction in small airways. Also, we found an increase in VTG after provocation with methacholine, suggesting hyperreactivity in the small airways. The increase in VTG (in combination with the lack of full reversibility to initial VTG after salbutamol) despite a normal $\mathrm{FEV}_{1}$ might be due to residual spasm in small airways. Such a reaction pattern is also often seen in exercise induced asthma. ${ }^{13}$ The VTG is a sensitive indicator of asthma and might increase to well over $1000 \mathrm{ml}$ in clinical asthma. ${ }^{13}$

The small initial increase in VTG among welders after inhalation at the lowest concentration of $0.001 \%$ methacholine is not specific but due to reaction to the saline of the aerosol and it indicates highly reactive small airways. We have seen similar reactions when giving a nebulised inhalation of physiological saline to subjects with known bronchial hyperreactivity (unpublished observation).

The increase in VTG and reactivity were not

Table 1 Static and dynamic lung volumes and wash out volumes in 14 welders and 14 controls

\begin{tabular}{|c|c|c|c|}
\hline \multirow{2}{*}{$\begin{array}{l}\text { Lung } \\
\text { function } \\
\text { variable }\end{array}$} & \multirow{2}{*}{$\frac{\text { Welders }(n=14)}{\text { Mean (range) }}$} & \multirow{2}{*}{$\frac{\text { References }(n=14)}{\text { Mean (range) }}$} & \multirow{2}{*}{$\begin{array}{l}\text { Mann-Whitney } \\
\text { U test } \\
\text { p Value }\end{array}$} \\
\hline & & & \\
\hline $\begin{array}{l}\text { VC } \\
\text { TLC } \\
\text { RV } \\
\text { FEV }_{1} \\
\text { WOV }\end{array}$ & $\begin{array}{r}100(88-123) \\
106(89-128) \\
119(85-159) \\
105(89-123) \\
91(68-111)\end{array}$ & $\begin{array}{r}98(85-121) \\
98(85-120) \\
97(66-139) \\
100(86-116) \\
96(69-141)\end{array}$ & $\begin{array}{l}0.55 \\
0.04 \\
0.02 \\
0.30 \\
0.44\end{array}$ \\
\hline
\end{tabular}

Mean and range are \% predicted values.

VC = Vital capacity; TLC = total lung capacity; RV = residual volume; $\mathrm{FEV}_{1}=$ forced expiratory volume in one second; WOV $=$ wash out volume. 
Table 2 Methacholine provocation test for welders and references before and after inhalation of methacholine for two minutes at stepwise increased concentrations, and after inhalation of salbutamol (Ventolin)

\begin{tabular}{|c|c|c|c|c|}
\hline \multirow[b]{2}{*}{ Before provocation } & \multirow[b]{2}{*}{$\begin{array}{l}\text { VTG } \\
\text { VTG/TLC }_{\text {FEV }_{1}}\end{array}$} & $\begin{array}{l}\text { Welders ( } n=14) \\
\text { Mean (range) }\end{array}$ & $\begin{array}{l}\text { References }(n=14) \\
\text { Mean (range) }\end{array}$ & \multirow{2}{*}{$\begin{array}{l}\text { Mann-Whitney } \\
\text { U test } \\
\text { p Value } \\
0.06 \\
0.08 \\
0.29\end{array}$} \\
\hline & & $\begin{array}{ll}127 & (63-210) \\
1 \cdot 76 & (1 \cdot 00-2 \cdot 80) \\
105 & (89-125)\end{array}$ & $\begin{array}{cl}98 & (71-159) \\
1.38 & (1 \cdot 00-2 \cdot 00) \\
100 & (86-116)\end{array}$ & \\
\hline $\begin{array}{l}\text { Methacholine } \\
\text { concentration } \\
0.001 \%\end{array}$ & $\begin{array}{l}\text { VTG } \\
\text { VTG/TLC } \\
\text { FEV }_{1}\end{array}$ & $\begin{aligned} 142 & (74-291) \\
1.90 & (1 \cdot 10-3 \cdot 60) \\
106 & (81-123)\end{aligned}$ & $\begin{array}{cl}92 & (66-115) \\
1.31 & (1 \cdot 00-1 \cdot 70) \\
100 & (85-116)\end{array}$ & $\begin{array}{l}0.09 \\
0.01 \\
0.15\end{array}$ \\
\hline $0.01 \%$ & $\begin{array}{l}\text { VTG } \\
\text { VTG/TLC } \\
\text { FEV }_{1}\end{array}$ & $\begin{array}{ll}133 & (69-360) \\
1 \cdot 86 & (1 \cdot 00-4 \cdot 60) \\
105 & (78-128)\end{array}$ & $\begin{aligned} 93 & (52-142) \\
1 \cdot 28 & (1 \cdot 00-1 \cdot 70) \\
101 \quad & (86-114)\end{aligned}$ & $\begin{array}{l}0.04 \\
0.01 \\
0.28\end{array}$ \\
\hline $0 \cdot 1 \%$ & $\begin{array}{l}\text { VTG } \\
\text { VTG/TLC } \\
\text { FEV }_{1}\end{array}$ & $\begin{array}{cl}164 & (87-379) \\
2 \cdot 29 & (1 \cdot 30-6 \cdot 30) \\
105 & (78-126)\end{array}$ & $\begin{aligned} 104 & (54-171) \\
1 \cdot 41 & (1 \cdot 00-2 \cdot 20) \\
101 & (86-117)\end{aligned}$ & $\begin{array}{l}0.02 \\
0.01 \\
0.34\end{array}$ \\
\hline $1 \%$ & $\begin{array}{l}\text { VTG } \\
\text { VTG/TLC } \\
\text { FEV }\end{array}$ & $\begin{array}{ll}324 & (87-744) \\
4 \cdot 76 & (1 \cdot 40-12 \cdot 50) \\
102 & (78-126)\end{array}$ & $\begin{array}{ll}168 & (67-310) \\
2 \cdot 29 & (1 \cdot 20-3 \cdot 70) \\
100 & (86-114)\end{array}$ & $\begin{array}{l}0.02 \\
0.03 \\
0.71\end{array}$ \\
\hline $2 \%$ * & $\begin{array}{l}\text { VTG } \\
\text { VTG/TLC } \\
\text { FEV }_{1}\end{array}$ & $\begin{aligned} 359 & (123-827) \\
5.00 & (1 \cdot 70-9 \cdot 70) \\
99 & (68-118)\end{aligned}$ & $\begin{array}{ll}228 & (119-465) \\
2.93 & (1.60-5.90) \\
102 & (92-110)\end{array}$ & $\begin{array}{l}0.16 \\
0.09 \\
0.89\end{array}$ \\
\hline After salbutamol $\dagger$ & $\begin{array}{l}\text { VTG } \\
\text { VTG/TLC } \text { FEV }_{1}\end{array}$ & $\begin{array}{cl}183 & (90-386) \\
2 \cdot 52 & (1 \cdot 30-4 \cdot 60) \\
104 & (79-129)\end{array}$ & $\begin{aligned} 100 & (70-137) \\
1.43 & (1 \cdot 10-1 \cdot 80) \\
101 & (89-113)\end{aligned}$ & $\begin{array}{l}0.01 \\
0.01 \\
0 \cdot 68\end{array}$ \\
\hline
\end{tabular}

$\star$ Eight welders, six controls.

tEleven welders, seven controls.

VTC in $\mathrm{ml}$ and $\%$ of TLC; FEV 1 as \% predicted value.

positively correlated to time of welding. A possible explanation is that welders who have increased reactivity in their airways tend to develop symptoms and leave welding. Welders have been reported to be absent from work due to bronchial symptoms more often than referents. ${ }^{14}$

Among non-smoking and ex-smoking arc welders abnormality in small airways function has been reported as changes in closing volume, closing capacity, and maximum amplitude of the cardiogenic oscillations during phase III of the single breath nitrogen wash out. ${ }^{7}$ Increased VTG is in full accord with these findings. Reduced pulmonary diffusion capacity for carbon monoxide and engagement of small airways have been found among welders with peripheral lung fibrosis. ${ }^{15}$ Welders with more than 10 years of exposure to welding fumes have an increased prevalence of chronic bronchitis and asthma. ${ }^{6}$ An increase of bronchial reactivity among arc welders has been found after acetylcholine inhalation and obstructive lung disease has been found among highly exposed welders working in confined spaces. ${ }^{15}$

For the early diagnosis of welding bronchitis the use of expiratory flow volume curves $\left(V_{50}, V_{75}\right.$, peak expiratory flow) have been used but have limitations due to their large variability ${ }^{16} ; \mathrm{FEV}_{1}$, on the other hand, is a more reliable measurement of impairment of lung function, with a low variability in repeated measurements. In the present study $F E V_{1}$ in the welder group was not different from that in the reference group, indicating normal large airways. Thus measurement of $\mathrm{FEV}_{1}$ alone or in combination with a methacholine provocation test seems insufficiently sensitive to detect a symptom free obstructive disease at this stage when still confined to small airways.

The adverse effect of welding fume on shipyard welders has been found to be affected by atopy and personal smoking. ${ }^{16}$ Our findings, however, indicate a small airways dysfunction among shipyard welders in the absence of atopy and smoking.

An increase in VTG is also in accordance with morphological findings of bronchiolitis in small airways where goblet cell metaplasia, inflammatory infiltrates, and increase in connective tissue with peribronchial fibrosis have been found. ${ }^{17}$

Because prevalence of asthmatic symptoms among welders is high, a strong selection of healthy welders probably exists. In the company employment lists we found few welders still working up to the retirement age of 65 years. The 
increase of VTG found thus underestimates the true prevalence of small airways dysfunction among welders.

\section{Requests for reprints to: Dr Ulf Hjortsberg, Department of Occupational Medicine, Malmö} General Hospital, S-214 01 Malmö, Sweden.

1 Hogg JC, Macklem PT, Thurlbeck WM. Site and nature of airway obstruction in chronic obstructive lung disease. New Engl J Med 1968;278:1355-69.

2 Macklem PT. Obstruction in small airways. A challenge to medicine. Am J Med 1972;52:721-4.

3 Dahlqvist $M$, Alexandersson R, Nielsen J, Hedenstierna G. Single and multiple breath nitrogen wash-out-closing volume and volume of trapped gas for detection of early airway obstruction. Clin Physiol 1989;9:389-98.

4 Niewohner E, Kleinerman J, Rice DB. Pathological changes in the peripheral airways of young cigarette smokers. New Engl J Med 1974;291:755-8.

5 Albert RE, Lippman M, Peterson HT, Berger J, Sanborn K, Bohning P. Bronchial deposition and clearance of aerosols. Archives of Internal Medicine 1973;131:115-27.

6 Hunnicut TN, Cracovaner DJ, Myles JT. Spirometric measurements in welders. Arch Environ Health 1964;8:661-9.

7 Oxhøj H, Bake B, Wedel H, Whilhelmsen L. Effect of electric arc welding on ventilatory lung function. Arch Environ Health 1979;32:211-7.

8 Lilja B, Arborelius M Jr, Janzon L. Länsimies E, Lindell
S-E. The volume of trapped gas, closing volume and pulmonary gas exchange in smokers and non-smokers aged 60. Scandinavian Journal of Respiratory Diseases 1976;Suppl 95:48-59.

9 Christensson P, Arborelius Jr M, Kautto R. Volume of trapped gas in lungs of healthy humans. $J$ Appl Physiol 1981;51:172-5.

$10 \mathrm{H}$ jortsberg U, Arborelius Jr M, Ørbæk P. Small airway dysfunction among non smoking isocyanate exposed workers. $\mathrm{Br} J$ Ind Med 1987;44:824-8.

11 Dahlbäck M, Nerbrink O, Arborelius Jr M, Hansson HC. Output characteristics from three medical nebulisers. Journal of Aerosols Science 1986;17:563-4.

12 Hjortsberg U, Ørbæk P, Arborelius Jr M, Ranstam J, Welinder $H$. Small airway dysfunction among asbestos exposed railroad workers with pleural plaques. Am J Ind Med 1988;14:643-7.

13 Svenonius E, Lecerof H, Lilja B, Arborelius Jr M, Kautto R. The volume of trapped gas: a new and sensitive test for the detection of exercise-induced bronchospasm in children. Acta Paediatr Scand 1978;67:583-9.

14 Wittgens von H. Zur frage der "Schweisserkrankheit". Zentralblatt fur Arbeitsmedizin und Arbeitsschutz 1962;12:105-12.

15 Mur JM, Teculescu D, Pham QT, Gaertner M, Massin N, Meyer-Bisch C, et al. Lung function and clinical findings in a cross-sectional study of arc welders. Int Arch Occup Environ Health 1985;57:1-17.

16 Chinn DJ, Stevenson IC, Cotes JE. Longitudinal respiratory survey of shipyard workers: effects of trade and atopic status. Br J Ind Med 1990;47:91-8.

17 Hogg JC, Cosio M. The pathophysiology of small airways. In: Sadoul P, Milic-Emili J, Simonsson BG, Clark TIH (eds). Small airways in health and disease. Proceedings of a symposium, Copenhagen, 29-30 March 1979. Amsterdam: Excerpta Medica, 33-9.

Accepted 7 October 1991 